\title{
Plasma diamine oxidase level predicts 6- month readmission for patients with hepatitis B virus-related decompensated cirrhosis
}

Feng-Cai Li ${ }^{1,2}$, Yu-Chen Fan ${ }^{1,2}$, Yue-Kai Li ${ }^{3}$ and Kai Wang ${ }^{1,2^{*}}$

\begin{abstract}
Background and aims: Hepatitis B virus-related decompensated cirrhosis is difficult to cure but has a high readmission rate due to multiple complications. Our aim was to investigate the diagnostic potential value of plasma diamine oxidase (DAO) for 6-month readmission of patients with HBV-related decompensated cirrhosis.

Methods: A total of 135 patients with HBV-related decompensated cirrhosis were prospectively collected at the onset of discharge of hospital, and then were followed up for at least 6 months with the readmission as the primary outcome. The plasma DAO level was measured using enzyme linked immunosorbent assay. In addition, 120 age and sex matched patients with HBV-related compensated cirrhosis were included as controls.

Results: A total of 36 patients (36.7\%) with decompensated cirrhosis admitted to hospital during the 6-month follow up. The plasma DAO level of readmission group $[21.1(14.5 ; 29.0) \mathrm{ng} / \mathrm{ml}]$ was significantly higher than that in the nonreadmission group $[12.7(9.3 ; 18.0) \mathrm{ng} / \mathrm{mL}, P<0.001]$. Multivariate analysis showed that the plasma DAO level $(H R=1.102$, $P<0.05)$ and hepatic encephalopathy $(\mathrm{HE})(\mathrm{HR}=5.018, P<0.05)$ were independent factors for 6 -month readmission of decompensated cirrhosis. DAO level showed higher area under the curve of receiver operating characteristic (AUROC) than HE (0.769 vs. $0.598, P<0.05)$ and Child-Pugh-Turcotte $(C P T)$ score $(0.769$ vs. $0.652, P<0.05)$ for predicting 6-month readmission rate, with the best cut-off value as $19.7 \mathrm{ng} / \mathrm{mL}$. Furthermore, plasma DAO level $(H R=1.184, P<0.05)$ was an independent factor and has the higher AUROC than CPT score for the onset of recurrent HE $(0.905 \mathrm{vs} .0 .738, P<0.05)$ during the 6-month follow up.
\end{abstract}

Conclusions: Plasma DAO level > $19.7 \mathrm{ng} / \mathrm{mL}$ predicts high rate of 6-month readmission in patients with HBV-related decompensated cirrhosis.

Keywords: Decompensated liver cirrhosis, Hepatitis B virus, Intestinal microecology, Diamine oxidase, Readmission

\section{Introduction}

Liver cirrhosis is a chronic, progressive, diffuse fibrosis of the liver which is mainly caused by hepatitis B virus (HBV) infection in China [1, 2]. Annually, 3\% 5\% of liver cirrhosis will develop to the decompensated state from compensated state, and the 5-year survival rate of decompensated cirrhosis is only about $14 \% \sim 35 \%$ [3].

\footnotetext{
*Correspondence: wangdoc876@126.com

'Department of Hepatology, Qilu Hospital of Shandong University, Wenhuaxi Road 107\#, Jinan 250012, China

${ }^{2}$ Institute of Hepatology, Shandong University, Wenhuaxi Road 107\#, Jinan 250012, China

Full list of author information is available at the end of the article
}

Patients with decompensated cirrhosis would experience the frequent hospitalization and eventually die of ascites, gastrointestinal bleeding, spontaneous peritonitis (SBP), hepatic encephalopathy (HE), etc. [4]. Liver cirrhosis causes huge economic burden to society and family, decompensated cirrhosis causes more economic burden because of repeated hospitalization [5]. Therefore, it is very important to assess the liver function of liver cirrhosis patients in detail and clarify the factors of readmission. Currently, Child-Pugh-Turcotte (CPT) score system is mainly used to evaluate the liver function of liver cirrhosis patients, which reflects the liver function

(c) The Author(s). 2019 Open Access This article is distributed under the terms of the Creative Commons Attribution 4.0 International License (http://creativecommons.org/licenses/by/4.0/), which permits unrestricted use, distribution, and 


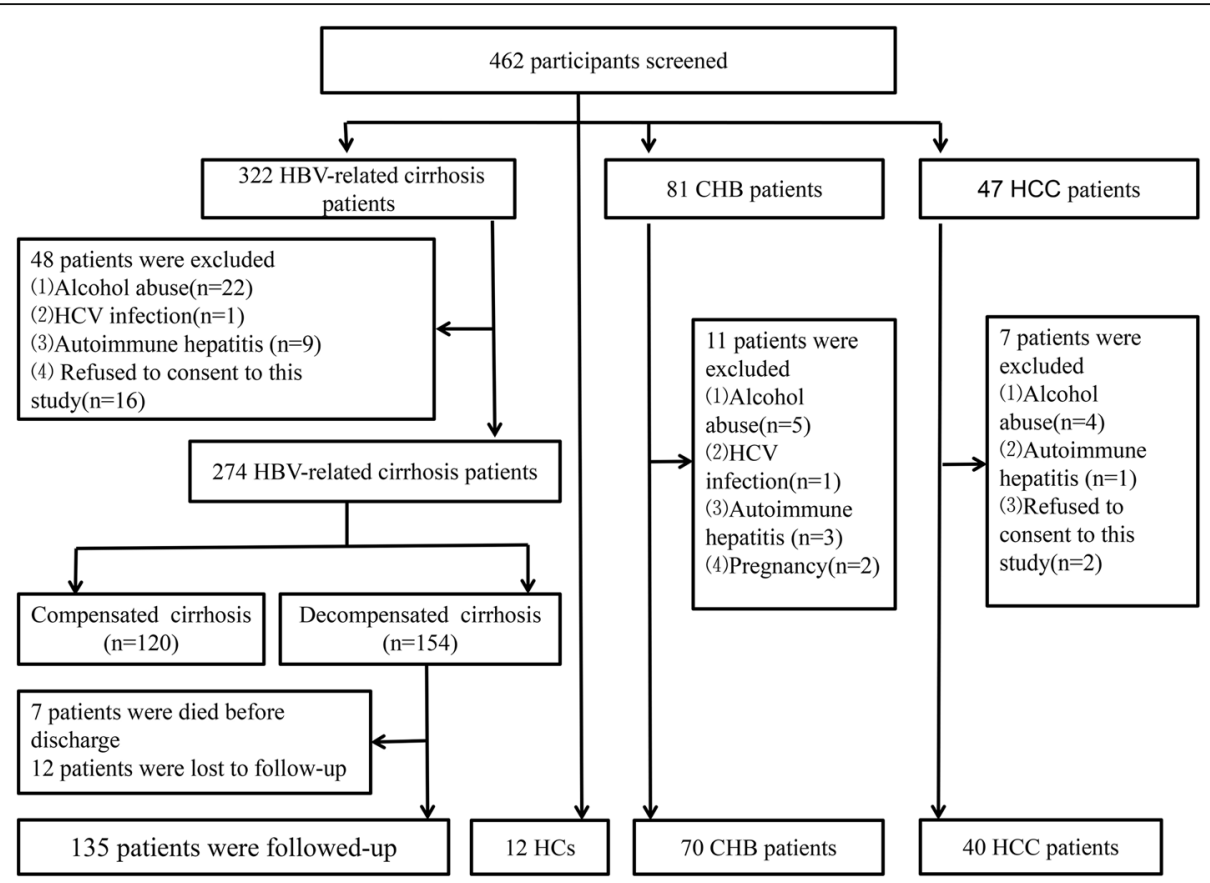

Fig. 1 Flowchart depicting the selection and exclusion process of the participants

Table 1 Characteristics of the research objects

\begin{tabular}{|c|c|c|c|c|c|c|}
\hline & \multicolumn{2}{|l|}{ LC $(n=255)$} & \multirow{2}{*}{$\begin{array}{l}\mathrm{CHB} \\
(n=70)\end{array}$} & \multirow{2}{*}{$\begin{array}{l}\mathrm{HCC} \\
(n=40)\end{array}$} & \multirow{2}{*}{$\begin{array}{l}\mathrm{HCs} \\
(n=12)\end{array}$} & \multirow[t]{2}{*}{$P$ value } \\
\hline & $\begin{array}{l}\text { Decompensated } \\
(n=135)\end{array}$ & $\begin{array}{l}\text { Compensated } \\
(n=120)\end{array}$ & & & & \\
\hline Male* (\%) & $96(71.1 \%)$ & $84(70 \%)$ & $51(72.9 \%)$ & $32(80 \%)$ & $9(75 \%)$ & 0.145 \\
\hline Age (year) & $63(53.5-68)$ & $58(50-62)$ & $49(40-54)$ & $55.5(39.25-66)$ & $50(40.25-51.5)$ & 0.217 \\
\hline $\mathrm{HBeAg}^{*}(+), \mathrm{n}(\%)$ & $90(66.7 \%)$ & $63(52.5 \%)$ & 49 (70\%) & $20(50 \%)$ & NA & 0.152 \\
\hline $\mathrm{HBsAg}$ & 4416 (3325-7081) & 4453 (3566-6266) & $5746(2926-7081)$ & $4478.5(3785-62,00)$ & NA & 0.081 \\
\hline HBV-DNA* (+), n(\%) & 99 (73.3\%) & $90(75 \%)$ & $59(84.3 \%)$ & $32(80 \%)$ & NA & 0.095 \\
\hline ALT (IU/L) & $78.5(63-129.5)$ & $111.5(72.25-237.75)$ & $282(238-468)$ & $66.5(39.5-238.25)$ & $31(24-34.5)$ & 0.000 \\
\hline AST (IU/L) & $70.5(51-96)$ & $86.5(51.25-113.5)$ & $210.5(183-359)$ & $53(36.25-133.75)$ & $33(25.25-37.75)$ & 0.015 \\
\hline TBIL ( $\mu \mathrm{mol} / \mathrm{L})$ & $39.1(26.2-58.7)$ & $36.85(23.85-49.45)$ & $20.9(14.6-27.5)$ & 37 (19-73.25) & $13.25(12.525-15.225)$ & 0.003 \\
\hline $\mathrm{ALB}(\mathrm{g} / \mathrm{L})$ & $31.35(29.32-34.95)$ & 34.75 (32.4-36.9) & $44.6(42.4-51)$ & $36.9(31-43.63)$ & $47.6(43.525-51.775)$ & 0.000 \\
\hline PTA (\%) & $67(60-84)$ & 81.5 (74-90.75) & $92(89.5-104)$ & 79.5 (64.5-90) & $91(85.75-101.25)$ & 0.000 \\
\hline $\mathrm{Cr}(\mu \mathrm{mol} / \mathrm{L})$ & 75 (66.5-89.75) & $74(66.5-86.5)$ & $76.5(70-87)$ & $88(70.25-92.25)$ & $70.5(64.25-79.75)$ & 0.216 \\
\hline WBC $\left(10^{9} / L\right)$ & $4.82(3.16-9.34)$ & $5.87(4.48-7.29)$ & $6.64(5.28-7.53)$ & $4.57(3.315-5.65)$ & $6.85(5.0-7.66)$ & 0.383 \\
\hline $\mathrm{HGB}(\mathrm{g} / \mathrm{L})$ & 119.5 (107-135.75) & $130(117-140.75)$ & $148(145-151)$ & $130(108-136)$ & 146.5 (135.75-149.75) & 0.000 \\
\hline $\operatorname{PLT}\left(10^{9} / \mathrm{L}\right)$ & $90.5(55-105)$ & $101(88.25-144.5)$ & $168.5(145-205)$ & $124(76-200)$ & 197.5 (176.5-239.5) & 0.000 \\
\hline $\mathrm{SBP}^{*},(\mathrm{n}, \%)$ & $21(15.6 \%)$ & NA & NA & NA & NA & NA \\
\hline Ascites*, $(n, \%)$ & $112(83 \%)$ & NA & NA & NA & NA & NA \\
\hline Gl bleeding*, $(n, \%)$ & $27(20 \%)$ & NA & NA & NA & NA & NA \\
\hline$H E^{*},(n, \%)$ & $18(13.3 \%)$ & NA & NA & NA & NA & NA \\
\hline Child-pugh $\mathrm{A} / \mathrm{B} / \mathrm{C}^{*}, \mathrm{n}(\%)$ & 0/90/45 (0/66.7\%/33.3\%) & $72 / 48 / 0(60 \% / 40 \% / 0 \%)$ & NA & NA & NA & 0.000 \\
\hline
\end{tabular}

HBeAg Hepatitis B e antigen, HBsAg Hepatitis B surface antigen, ALT Alanine aminotransferase, AST Aspartate aminotransferase, TBIL Total bilirubin, ALB Albumin, PTA Prothrombin activity; Cr Creatinine, WBC White blood cell, HGB Haemoglobin, PLT Platelet, SBP Spontaneous bacterial peritonitis, GI bleeding, Gastrointestinal bleeding, HE Hepatic encephalopathy

Quantitative variables were expressed as the median (centile 25; centile 75)

* Categorical variables were expressed as $n(\%)$ 
based on ascites, encephalopathy, albumin, bilirubin, clotting function [6], among them, there are subjective factors for the classification of ascites and hepatic encephalopathy, which may affect the determination of $\mathrm{CPT}$ values. Further, the CPT score system is not based on the Chinese cohort, and cannot predict and evaluate the readmission rate of patients with $\mathrm{HBV}$-related decompensated cirrhosis. Therefore, new indicators are urgently needed to assess the readmission to hospital and severity for HBV-related decompensated cirrhosis.

At present, many studies have suggested that the imbalance of intestinal microecology is involved in the occurrence and development of multiple complications of decompensated cirrhosis [7-11]. The liver and the intestine are closely connected through the "Gut-Liver axis" [12]. In cirrhosis the intestinal microenvironment is directly or indirectly affected by liver damage and portal hypertension. Studies have shown that the stability of intestinal micro-ecological system is mainly related to the following aspects: excessive growth of intestinal bacteria, increased permeability of intestinal wall and decreased immunity $[13,14]$. Increased permeability of intestinal wall can cause intestinal bacteria or their metabolites to shift and enter the body's blood circulation, entering the liver through the portal system, further impairing liver function, leading to complications such as SBP, HE and other complications [15].
DAO is a kind of protein with molecular weight of 84 , 000 [16]. DAO is a highly active intracellular enzyme, closely related to nucleic acid and protein synthesis in the intestinal mucosa. Luk GD et al. first confirmed that plasma DAO is an indicator of intestinal mucosal maturation and barrier function in rats in 1980 [17]. Subsequently, many scholars confirmed that the changes of DAO activity could reflect the damage and repair of intestinal mucosal barrier function [18, 19]. So far, plasma DAO level has been demonstrated to be related to the development, progression and prognosis of many diseases, such as lung small-cell carcinoma and inflammatory bowel disease [20, 21]. Our previous work demonstrated that plasma DAO level can predict the short-term survival rate of acute-on-chronic hepatits $B$ liver failure (ACHBLF) [22]. At present, it has been suggested that plasma DAO level is related to liver cirrhosis $[23,24]$.

However, there is no data on plasma DAO as a biomarker for predicting readmission rate in HBV-related decompensated cirrhosis. In this study, plasma DAO levels in decompensated cirrhosis patients were measured to determine whether the plasma DAO was associated with the severity and complications of HBV-related decompensated cirrhosis. In addition, decompensated cirrhosis patients were followed up for at least 6 months to further evaluate the diagnostic value of DAO as a

Table 2 Characteristics of the HBV-related decompensated cirrhosis patients

\begin{tabular}{|c|c|c|c|}
\hline & Readmission $(n=36)$ & Non-Readmission ( $n=135)$ & $P$ Value \\
\hline Male* (\%) & $28(77.8 \%)$ & $68(68.7 \%)$ & 0.303 \\
\hline Age (year) & $59(53-61.6)$ & $58(53-61)$ & 0.574 \\
\hline $\operatorname{HBeAg}(+)^{*}, \mathrm{n}(\%)$ & $27(75 \%)$ & $63(63.6 \%)$ & 0.215 \\
\hline $\mathrm{HBsAg}$ & $4122.5(3276.3-6266.0)$ & 4477.0(3634.0-6326.0) & 0.282 \\
\hline HBV-DNA(+)*, n(\%) & $27(75 \%)$ & $72(72.7 \%)$ & 0.792 \\
\hline ALT (IU/L) & $72.0(54.3-109.5)$ & $85.0(65.0-132.0)$ & 0.105 \\
\hline AST (IU/L) & $91.0(55.0-145.5)$ & $79.0(45.0-114.0)$ & 0.307 \\
\hline TBIL ( $\mu \mathrm{mol} / \mathrm{L})$ & $41.4(26.1-67.9)$ & $39.8(27.0-56.9)$ & 0.508 \\
\hline ALB (g/L) & $30.9(26.7-34.6)$ & $34.6(32.0-37.9)$ & 0.042 \\
\hline PTA (\%) & $70.0(61.3-85.8)$ & $75.0(63.0-88.0)$ & 0.233 \\
\hline $\mathrm{Cr}(\mu \mathrm{mol} / \mathrm{L})$ & $89.0(68.5-93.8)$ & $73.0(66.0-87.0)$ & 0.087 \\
\hline WBC $\left(10^{9} / \mathrm{L}\right)$ & $4.5(2.9-9.0)$ & $4.7(3.0-11.4)$ & 0.807 \\
\hline $\mathrm{HGB}(\mathrm{g} / \mathrm{L})$ & 115.5(89.5-129.8) & 125.0(111.0-137.0) & 0.019 \\
\hline $\operatorname{PLT}\left(10^{9} / \mathrm{L}\right)$ & $73.5(66.0-123.3)$ & $90.0(54.0-133.0)$ & 0.464 \\
\hline $\mathrm{SBP}^{*},(n, \%)$ & $10(27.8 \%)$ & $11(11.1 \%)$ & 0.018 \\
\hline Ascites*, $(n, \%)$ & $31(86.1 \%)$ & $81(81.8 \%)$ & 0.557 \\
\hline Gl bleeding*, $(n, \%)$ & $15(41.7 \%)$ & $12(12.1 \%)$ & 0.000 \\
\hline$H E^{*},(n, \%)$ & $10(27.8 \%)$ & $8(8.1 \%)$ & 0.003 \\
\hline Child-pugh A/B/C*, n(\%) & 0/16/20(0\%/44.4\%/55.6\%) & 0/74/25(0/74.7\%/25.3\%) & 0.001 \\
\hline
\end{tabular}

Quantitative variables were expressed as the median (centile 25; centile 75)

* Categorical variables were expressed as $\mathrm{n}(\%)$ 
a
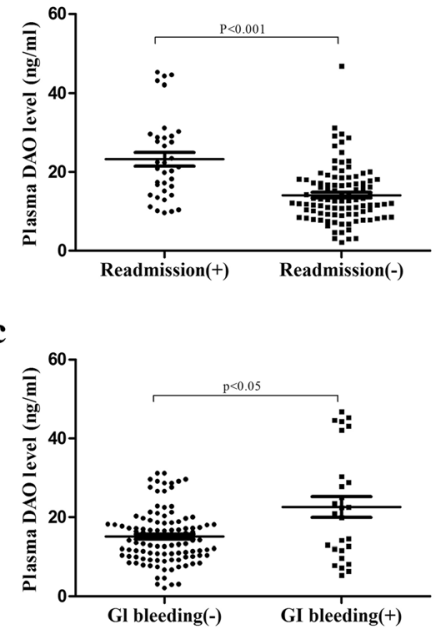

e

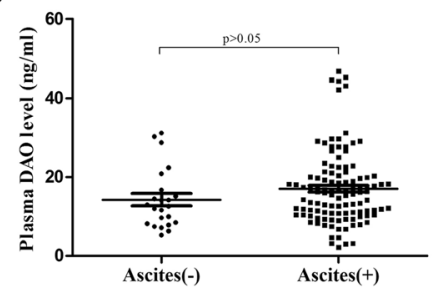

g

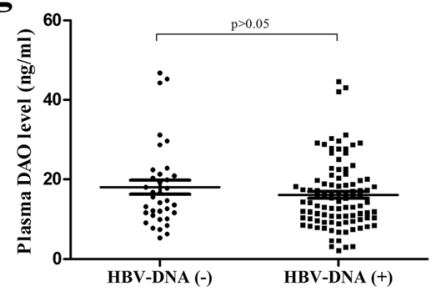

i

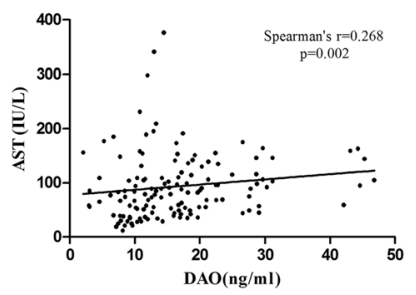

$\mathbf{k}$

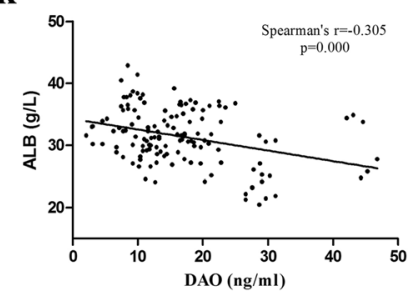

b

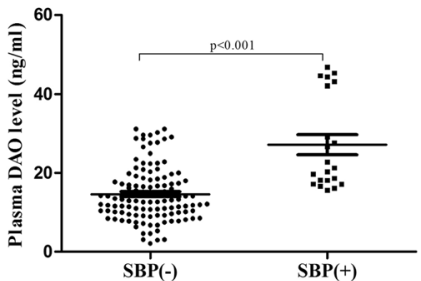

d

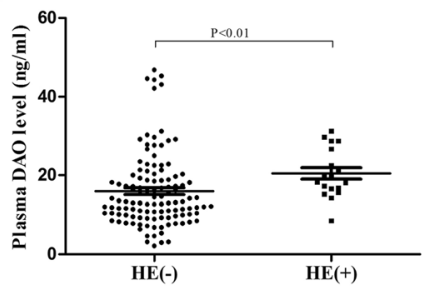

f

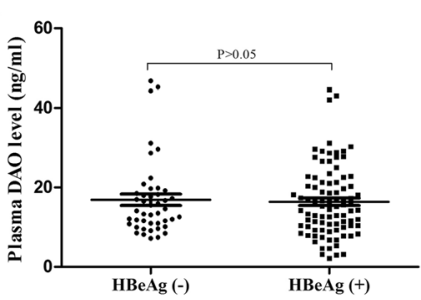

h

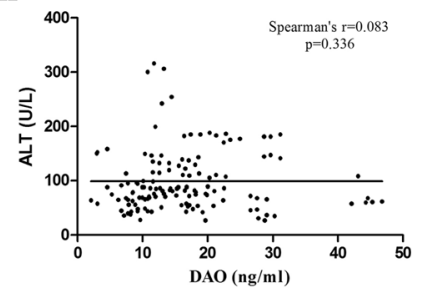

j

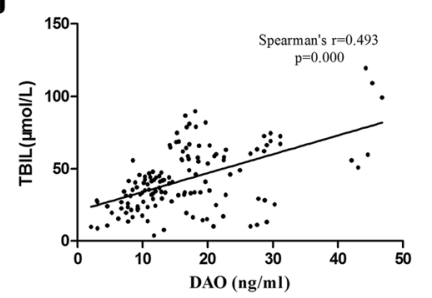

l

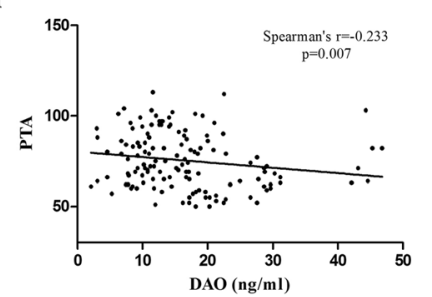

Fig. 2 (See legend on next page.) 


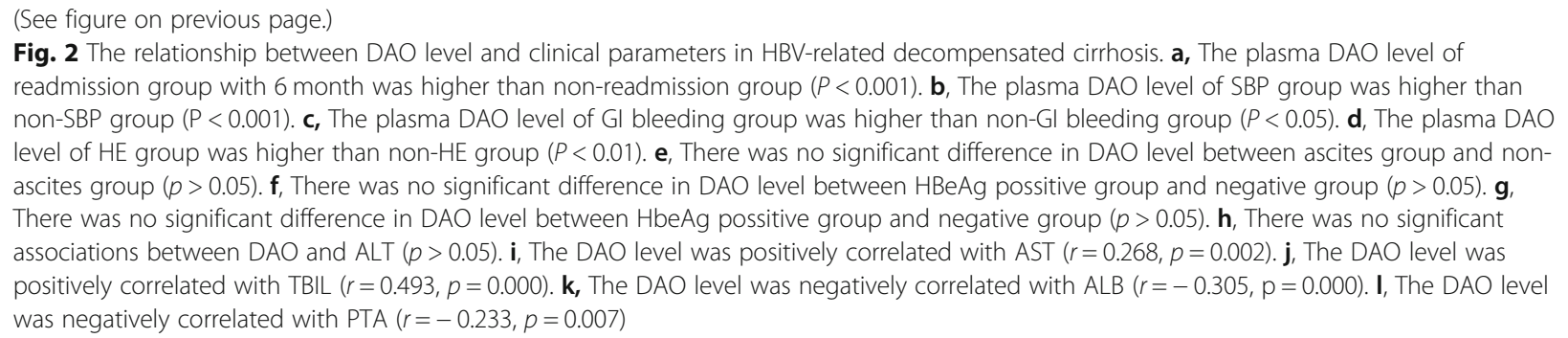

biological marker in the readmission rate of HBVrelated decompensated cirrhosis within 6 months.

\section{Methods}

\section{Research design and research characters}

A total of 135 newly diagnosed HBV-related decompensated cirrhosis patients were prospectively enrolled at Department of Hepatology, Qilu Hospital of Shandong University from January 2014 to December 2016. In addition, 70 age and sex matched Chronic Hepatitis B (CHB) patients, $120 \mathrm{HBV}$-related compensated cirrhosis patients, 40 hepatocellular carcinoma (HCC) patients and 12 healthy controls were included as controls. According to the guidelines of the Helsinki declaration, all participants were approved in writing by the local research and ethics committee of Qilu hospital of Shandong University [25] The flow chart of selecting and excluding research objects was shown in Fig. 1.

According to evidence-based clinical practice guidelines for liver cirrhosis 2015, HBV-related decompensated cirrhosis diagnosed standard: (1) Serum hepatitis B surface antigen (HBsAg) positive $\geq 6$ months; (2) liver histology or ultrasonography and other imaging suggested cirrhosis; (3) obvious decompensated liver function; (4) severe complications of cirrhosis, such as gastrointestinal bleeding, massive ascites, hepatorenal syndrome, SBP or HE. HBV-related compensated cirrhosis was diagnosed standard: (1) HBsAg positive $\geq 6$ months; (2) liver histology or ultrasonography and other imaging suggested cirrhosis; (3) abnormal liver function or portal hypertension, including hypersplenism and varicose esophageal and gastric fundus; (4) no serious complications of cirrhosis such as esophageal varices, ascites or HE [26]. The exclusion criteria were as follows: (1) alcohol abuse; (2) confirmed to merge with other hepatotropic infections; (3) autoimmune liver disease; (4) reject participate in this study.

The start date of follow-up was the diagnosed date of HBV-related decompensated cirrhosis. All decompensated patients were followed up by telephone and the hospital case retrieval system for at least 6 months. The end point of follow-up was readmission to hospital or not. During the follow-up, 7 patients died before the discharge, 12 patients were lost follow-up because they could not be contacted after discharge.

\section{Measurement of plasma DAO level using enzyme-linked immunosorbent assay (ELISA)}

On the morning of the second day of admission, $5 \mathrm{~mL}$ of fasting venous blood of study paricipants with EDTA as the anticoagulant was obtained. Centrifuged at $2000 \mathrm{r} /$ min for $5 \mathrm{~min}$ at room temperatureand and stored in refrigerator at $-80^{\circ} \mathrm{C}$. The plasma DAO level was determined using the highly sensitive Human diamine oxidase (DAO) enzyme-linked immunosorbent assay (ELISA) kit (Lengton, shanghai, China) according to the manufacturer's instructions. Briefly, 50uL standard, 40uL plasma samples were added into 96-well plated, respectively, $10 \mathrm{uL}$ anti-DAO antibody were added into the sample well, $50 \mathrm{uL}$ Streptavidin-HRP were added into 96-well plated, respectively. The wells were then covered with the seal plate membrane, gently mixed and incubated at $37^{\circ} \mathrm{C}$ for $60 \mathrm{~min}$. The contents of the wells were then aspirated and rinsed with wash buffer repeatedly five times. $50 \mathrm{uL}$ of detection reagent $\mathrm{A}$ was added to each well, and then detection reagent $\mathrm{B} 50 \mathrm{uL}$ was added to each well, and incubated for $30 \mathrm{~min}$ at $37^{\circ} \mathrm{C}$. Finally, $50 \mathrm{uL}$ stop solution was added to each well to terminate the reaction. The absorbance (OD value) of each hole was measured sequentially at the wavelength of $450 \mathrm{~nm}$ within $10 \mathrm{~min}$, and the DAO concentration was calculated. The sensitivity of the DAO ELISA kit is $0.78 \mathrm{ng} / \mathrm{mL}$.

\section{Clinical characteristics}

Alanine aminotransferase (ALT), aspartate aminotransferase (AST), total bilirubin (TBIL), albumin (ALB) and creatinine $(\mathrm{Cr})$ were measured by COBAS integra 800 (Roche Diagnostics, Germany). PTA was quantifified using ACL TOP 700 (Instrument Laboratory, Lexington, USA). Hepatitis B surface antigen (HBsAg) and hepatitis $\mathrm{B}$ e antigen $(\mathrm{HBeAg})$ were measured by COBAS 6000 analyzer series (Roche Diagnostics, Basel, Switzerland). HBV-DNA load was measured by ABI 7300 PCR System (Applied Biosystems, USA). WBCs, HGB, PLTs were measured by Sysmex XE-2100 (Chuoku, Kobe, Japan). All the clinical parameters were measured using 
standard laboratory methods at the Department of Laboratory Medicine, Qilu Hospital of Shandong University.

\section{Statistical analysis}

The IBM SPSS19.0 software (SPSS Inc., Chicago, USA) and MedCalc 15.6 software (MedCalc Software, Ostend, Belgium) were used for statistical analysis. The
Kolmogorov-Smirnov test was used to determine whether the data came from a normally distributed population. Categorical variables were represented by frequencies (\%). Continuous variables were represented by median (centile 25; centile 75 ). Chi-square test was used for Categorical variables, and Mann-Whitney U test and the Wilcoxon signed rank test were used for continuous variables. Spearman correlation analysis was

Table 3 The characters of the readmission patients with hepatitis B virus-related decompensated cirrhosis

\begin{tabular}{|c|c|c|c|c|c|c|c|c|c|}
\hline Cases & Gender & $\begin{array}{l}\text { Age } \\
\text { (years) }\end{array}$ & $\begin{array}{l}\text { Child-pugh score } \\
\text { (A/B/C) }\end{array}$ & $\begin{array}{l}\text { SBP } \\
(+/-)\end{array}$ & $\begin{array}{l}\text { Ascites } \\
(+/-)\end{array}$ & $\begin{array}{l}\text { Gl bleeding } \\
(+/-)\end{array}$ & $\begin{array}{l}\mathrm{HE} \\
(+/-)\end{array}$ & $\begin{array}{l}\text { Readmission } \\
\text { Reasons }\end{array}$ & $\begin{array}{l}\text { Readmission } \\
\text { Time (months) }\end{array}$ \\
\hline 1 & Male & 55 & C & + & + & + & - & HE and ascites & 0.25 \\
\hline 2 & Male & 53 & B & - & + & + & - & Gl bleeding & 4.75 \\
\hline 3 & Male & 41 & C & - & + & - & + & $\mathrm{HE}$ & 0.95 \\
\hline 4 & Female & 61 & C & - & + & + & + & SBP and ascites & 5.40 \\
\hline 5 & Male & 55 & B & - & - & + & - & Gl bleeding & 5.20 \\
\hline 6 & Male & 64 & C & + & + & + & - & HE & 2.80 \\
\hline 7 & Male & 53 & C & + & + & - & - & Gl bleeding and $\mathrm{HE}$ & 3.10 \\
\hline 8 & Male & 61 & B & + & + & - & - & HE and ascites & 2.30 \\
\hline 9 & Male & 57 & B & - & + & - & - & HE and ascites & 4.45 \\
\hline 10 & Male & 55 & C & + & + & + & - & SBP and ascites & 1.75 \\
\hline 11 & Male & 55 & B & - & + & - & - & Gl bleeding & 1.35 \\
\hline 12 & Female & 61 & C & - & + & + & + & SBP and ascites & 1.40 \\
\hline 13 & Female & 61 & C & - & + & + & + & Gl bleeding & 1.70 \\
\hline 14 & Male & 62 & B & - & + & - & + & Gl bleeding & 3.05 \\
\hline 15 & Male & 62 & B & - & + & - & + & SBP and ascites & 3.05 \\
\hline 16 & Male & 64 & C & + & + & + & - & HE & 5.65 \\
\hline 17 & Male & 64 & C & + & + & + & - & Gl bleeding and ascites & 1.15 \\
\hline 18 & Male & 53 & C & + & + & - & - & ascites & 2.10 \\
\hline 19 & Female & 66 & C & - & + & + & - & SBP and ascites & 1.45 \\
\hline 20 & Female & 66 & C & - & + & + & - & Gl bleeding & 1.05 \\
\hline 21 & Male & 53 & C & + & + & - & - & SBP and ascites & 5.10 \\
\hline 22 & Male & 41 & C & - & + & - & + & HE & 0.95 \\
\hline 23 & Male & 53 & B & - & + & + & - & Gl bleeding and ascites & 2.35 \\
\hline 24 & Male & 61 & B & + & + & - & - & Gl bleeding & 4.30 \\
\hline 25 & Female & 66 & C & - & - & + & - & SBP and ascites & 1.05 \\
\hline 26 & Male & 57 & B & - & + & - & - & Gl bleeding & 4.45 \\
\hline 27 & Male & 53 & B & - & + & - & - & ascites & 4.25 \\
\hline 28 & Male & 61 & B & - & - & - & + & SBP and ascites & 3.95 \\
\hline 29 & Male & 61 & B & - & - & - & + & Gl bleeding & 3.65 \\
\hline 30 & Male & 41 & C & - & + & - & + & $\mathrm{HE}$ & 1.53 \\
\hline 31 & Male & 58 & C & - & - & + & - & Gl bleeding & 2.50 \\
\hline 32 & Female & 39 & B & - & + & - & - & Gl bleeding & 3.05 \\
\hline 33 & Male & 59 & C & - & + & - & - & Gl bleeding & 2.95 \\
\hline 34 & Female & 59 & B & - & + & - & - & SBP and ascites & 4.25 \\
\hline 35 & Male & 59 & C & - & + & - & - & Gl bleeding & 2.95 \\
\hline 36 & Male & 69 & B & - & + & - & - & SBP and ascites & 5.10 \\
\hline
\end{tabular}


used to analyze the correlation between DAO and clinical and experimental data. Univariate Cox proportional hazards regression analyses was used to determine the risk factors for readmission of HBV-related decompensated cirrhosis patients, and covariates with $P<0.05$ were incorporated into the multivariate Cox proportional hazards regression analyses to determine the independent risk factors for readmission of HBV-related decompensated cirrhosis patients. Receiver operating characteristic (ROC) curve was used to evaluate the diagnostic value of DAO in the readmission of HBV-related decompensated cirrhosis patients. The readmission time for the cut-off values was compared using the Kaplan-Meier method. Bilateral $P<0.05$ was considered statistically significant.

\section{Results}

Basic parameters of the reasearch population

This study includes 135 patients with HBV-related decompensated cirrhosis. Meanwhile, 120 HBV-related compensated cirrhosis patients, $70 \mathrm{CHB}$ patients, 40 $\mathrm{HCC}$ patients and $12 \mathrm{HCs}$ as controls. The basic parameters of the research object were shown in Table 1.

The 6-month readmission rate for patients with HBVrelated decompensated cirrhosis was $26.7 \%(36 / 135)$. We compared the clinical indicators between readmission group and non-readmission group, as shown in Table 2 .
We discovered that the readmission group had lower median levels of ALB [30.9 (26.7-34.6) g/L vs. 34.6 (32.0-37.9) g/L, $P<0.05]$ and HGB [115.5 (89.5-129.8) g/L vs. $125.0(111.0-137.0) \mathrm{g} / \mathrm{L}, P<0.05]$ than nonreadmission group. Meanwhile, in readmission group, the incidences of SBP $(27.8 \%$ vs. $11.1 \%, P<0.05)$, GI bleeding $(41.7 \%$ vs. $12.1 \%, P<0.001)$ and $\mathrm{HE}(27.8 \%$ vs. $8.1 \%, P<0.05)$ were higher than non-readmission group. The rate of Child-pugh socre $C$ level was higher in readmission group than non-readmission $(55.6 \%$ vs. 25.3 , $P<0.05)$. There were no significant difference in sex, age, HBeAg, HBsAg, HBV-DNA, ALT, AST, TBIL, PTA, $\mathrm{Cr}, \mathrm{WBCs}$ and PLT between readmission group and non-readmission group.

\section{Plasma DAO level of study populations}

We detected the plasma DAO level of all study population. The DAO level of readmission group [21.1 (14.5; 29.0) $\mathrm{ng} / \mathrm{mL}$ ] was higher than non-readmission group [12.7 (9.3; 18.0) ng/mL, $P<0.001$ ] (Fig. 2a). The plasma DAO level of patients with decompensated cirrhosis [14.6 $(10.4 ; 20.3) \mathrm{ng} / \mathrm{mL}$ ] was significantly higher than patients with compensated cirrhosis $[9.4(6.2 ; 13.5) \mathrm{ng} / \mathrm{mL}, P<$ 0.001 ]. The plasma DAO level of patients with liver cirrhosis $[11.8(7.9 ; 17.7) \mathrm{ng} / \mathrm{mL}]$ was significantly higher than $\mathrm{CHB}$ patients $[4.9(3.3 ; 6.9) \mathrm{ng} / \mathrm{mL}, P<0.001]$, and

Table 4 Uni- and multivariate Cox analysis of factors associated with readmission in HBV-related decompensated cirrhosis patients

\begin{tabular}{|c|c|c|c|c|c|c|}
\hline \multirow[t]{2}{*}{ variable } & \multicolumn{3}{|c|}{ univariate } & \multicolumn{3}{|c|}{ mutlivariate } \\
\hline & $\overline{\mathrm{HR}}$ & $95 \% \mathrm{Cl}$ & $P$ & $\mathrm{HR}$ & $95 \% \mathrm{Cl}$ & $P$ \\
\hline Gender (male/female) * & 0.627 & $0.257-1.531$ & 0.305 & & & \\
\hline Age (year) & 1.066 & $0.957-1.057$ & 0.814 & & & \\
\hline $\operatorname{HBeAg}(+/-)^{*}$ & 1.000 & $0.445-2.246$ & 1.000 & & & \\
\hline $\mathrm{HBsAg}$ & 1.000 & $1.000-1.000$ & 0.669 & & & \\
\hline HBV-DNA $(+/-)^{*}$ & 1.125 & $0.469-2.697$ & 0.792 & & & \\
\hline ALT(IU/L) & 0.994 & $0.986-1.002$ & 0.120 & & & \\
\hline AST(IU/L) & 1.001 & $0.995-1.007$ & 0.763 & & & \\
\hline TBIL(umol/L) & 1.010 & $0.993-1.028$ & 0.246 & & & \\
\hline PTA & 0.984 & $0.959-1.010$ & 0.223 & & & \\
\hline $\mathrm{ALB}(\mathrm{g} / \mathrm{L})$ & 0.959 & $0.880-1.044$ & 0.334 & & & \\
\hline $\operatorname{WBC}\left(10^{9} / \mathrm{L}\right)$ & 1.053 & $0.952-1.165$ & 0.313 & & & \\
\hline $\mathrm{HGB}(\mathrm{g} / \mathrm{L})$ & 0.979 & $0.963-0.995$ & 0.010 & 0.980 & $0.942-1.019$ & 0.313 \\
\hline $\operatorname{PLT}\left(10^{9} / \mathrm{L}\right)$ & 0.996 & $0.987-1.004$ & 0.302 & & & \\
\hline $\mathrm{SBP}(+/-)^{*}$ & 3.077 & $1.176-8.049$ & 0.022 & 2.230 & $0.561-8.870$ & 0.255 \\
\hline $\operatorname{Ascites}(+/-)^{*}$ & 0.494 & $0.192-1.286$ & 0.143 & & & \\
\hline $\mathrm{HE}(+/-)^{*}$ & 4.375 & $1.567-12.215$ & 0.000 & 5.018 & $1.436-17.533$ & 0.012 \\
\hline Gl Bleeding $(+/-)^{*}$ & 5.179 & $2.113-12.690$ & 0.000 & 1.520 & $0.156-14.788$ & 0.718 \\
\hline Chilid-pugh score $(B / C) *$ & 3.700 & $1.665-8.223$ & 0.001 & 0.914 & $0.281-2.972$ & 0.881 \\
\hline $\mathrm{DAO}(\mathrm{ng} / \mathrm{mL})$ & 1.126 & $1.068-1.188$ & 0.000 & 1.102 & $1.023-1.188$ & 0.010 \\
\hline
\end{tabular}

HR Hazard ratio, Cl Confidence interval.

* Categorical variables 
lower than HCC patients $[18.3(13.4 ; 20.5) \mathrm{ng} / \mathrm{mL}, P<$ $0.001]$. The plasma DAO level of liver cirrhosis patients with child-pugh $B[12.6(9.3 ; 16.4) \mathrm{ng} / \mathrm{mL}]$ was higher than child-pugh A $[7.8(5.4 ; 9.9) \mathrm{ng} / \mathrm{mL}, P<0.001]$, and lower than child-pugh $C$ [22.4 $(16.5 ; 29.1) \mathrm{ng} / \mathrm{mL}, P<0.001]$.

\section{The realtionship between plasma DAO level and clinical parametes in HBV-related decompensated cirrhosis}

The DAO level of readmission group was higher than non-readmission group [21.1 (14.5; 29.0) vs. 12.7 (9.3; 18.0) $\mathrm{ng} / \mathrm{mL}, P<0.001$ ], as shown in Fig. 2a. The plasma DAO levels in SBP group, GI bleeding group, and HE group were higher than those non-SBP group[21.3 (17.6; $42.6)$ vs. $13.0(9.7 ; 18.5) \mathrm{ng} / \mathrm{mL}, P<0.001]$, non-GI bleeding group $[20.9(11.6 ; 30.3)$ vs. $14.2(10.3 . ; 18.6) \mathrm{ng} /$ $\mathrm{mL}, P<0.05]$ and non-HE group $[19.0(16.3 ; 27.1)$ vs. 13.3 (10.0; 19.5) ng/mL, $P<0.05]$, respectively. However, Plasma DAO levels were no statistically difference in the ascites-positive group, HBeAg-positive group, HBVDNA positive group and ascites-negative group [16.0 $(10.8$; 20.3) vs. $12.6(8.2 ; 16.7) \mathrm{ng} / \mathrm{mL}, P>0.05]$, HBeAgnegative group $[15.2(10.1 ; 21.3)$ vs. $14.1(10.9 ; 18.9) \mathrm{ng} /$ $\mathrm{mL}, P>0.05]$, and HBV-DNA negative group [15.5 (10.2; 19.7) vs. $15.1(11.2 ; 21.2) \mathrm{ng} / \mathrm{mL}, P>0.05]$, respectively, as shown in Fig. 2b-g. DAO level was positively correlated with AST $(r=0.268, p=0.002)$ and TBIL $(r=0.493, p=0.000)$, negatively correlated with ALB $(r=-0.305, p=0.000)$ and $\operatorname{PTA}(r=-0.233, p=$ 0.007). However, there was no significant associations between DAO level and ALT $(r=0.083, p=0.336)$ (Fig. 2h-l).

\section{The plasma DAO level was an inependent risk factor for readmission within 6 months of HBV-related decompensated cirrhosis}

The 6-month readmission rate for patients with HBVrelated decompensated cirrhosis was 26.7\%(36/135). Among the readmission patients, 5 had HE, 3 had HE with ascites, 1 had HE and GI bleeding, 12 had GI bleeding, 3 had GI bleeding and ascites, 2 had ascites, 10 had ascites and SBP, as shown in the Table 3.

We used univariate Cox regression analyses to detemine the risk factors for 6-month readmission of HBVrealted decompented cirrhosis, as shown in Table 4. The plasma DAO level $(\mathrm{HR}=1.126, P<0.001)$, the Childpugh score $(\mathrm{HR}=3.700, P<0.05)$, GI bleeding $(\mathrm{HR}=$ 5.179, $P<0.001)$, HE $(\mathrm{HR}=4.375, P<0.001)$, SBP $(\mathrm{HR}=$ 3.077, $P<0.001)$ and HGB $(\mathrm{HR}=0.979, P<0.05)$ were the risk factors for the 6-month readmission of HBVrelated decompensated cirrhosis. Then the above risk

Table 5 Uni- and multivariate Cox analysis of factors associated with readmission due to HE in HBV-related decompensated cirrhosis patients

\begin{tabular}{|c|c|c|c|c|c|c|}
\hline \multirow[t]{2}{*}{ variable } & \multicolumn{3}{|c|}{ univariate } & \multicolumn{3}{|c|}{ mutlivariate } \\
\hline & $\overline{H R}$ & $95 \% \mathrm{Cl}$ & $P$ & $\overline{\mathrm{HR}}$ & $95 \% \mathrm{Cl}$ & $P$ \\
\hline Gender (male/female) * & 0.000 & 0.000 & 0.998 & & & \\
\hline Age (year) & 0.940 & $0.869-1.017$ & 0.125 & & & \\
\hline $\operatorname{HBeAg}(+/-)^{*}$ & 0.603 & $0.154-2.365$ & 0.468 & & & \\
\hline $\mathrm{HBsAg}$ & 1.000 & $1.000-1.000$ & 0.762 & & & \\
\hline HBV-DNA $(+/-)^{*}$ & 0.426 & $0.108-1.682$ & 0.223 & & & \\
\hline ALT(IU/L) & 1.002 & $0.991-1.013$ & 0.673 & & & \\
\hline AST(IU/L) & 1.006 & $0.997-1.015$ & 0.179 & & & \\
\hline TBIL(umol/L) & 1.028 & $1.000-1.057$ & 0.049 & 0.985 & $0.950-1.020$ & 0.391 \\
\hline PTA & 0.949 & $0.897-1.004$ & 0.068 & & & \\
\hline $\operatorname{ALB}(\mathrm{g} / \mathrm{L})$ & 0.974 & $0.838-1.132$ & 0.733 & & & \\
\hline $\operatorname{WBC}\left(10^{9} / \mathrm{L}\right)$ & 1.115 & $0.948-1.312$ & 0.188 & & & \\
\hline $\mathrm{HGB}(\mathrm{g} / \mathrm{L})$ & 0.992 & $0.965-1.019$ & 0.550 & & & \\
\hline $\operatorname{PLT}\left(10^{9} / \mathrm{L}\right)$ & 0.994 & $0.978-1.010$ & 0.450 & & & \\
\hline $\mathrm{SBP}(+/-)^{*}$ & 8.594 & $2.087-35.394$ & 0.003 & 1.138 & $0.133-9.732$ & 0.906 \\
\hline $\operatorname{Ascites}(+/-)^{*}$ & 1.692 & $0.201-14.228$ & 0.628 & & & \\
\hline $\mathrm{HE}(+/-)^{*}$ & 3.700 & $0.836-16.37$ & 0.085 & & & \\
\hline Gl Bleeding $(+/-)^{*}$ & 2.125 & $0.596-9.109$ & 0.310 & & & \\
\hline Chilid-pugh score $(B / C) *$ & 8.105 & $1.609-40.828$ & 0.011 & 1.886 & $0.081-9.733$ & 0.921 \\
\hline $\mathrm{DAO}(\mathrm{ng} / \mathrm{mL})$ & 1.157 & $1.078-1.243$ & 0.000 & 1.184 & $1.024-1.369$ & 0.023 \\
\hline
\end{tabular}

HR Hazard ratio, Cl Confidence interval

* Categorical variables 
factors were analyzed by Cox Forward regression analyses, and it was found that the DAO level $(\mathrm{HR}=1.102, P<0.05)$ and $\mathrm{HE}(\mathrm{HR}=6.018, P<0.05)$ were independent risk factors for readmission within 6 months of HBV-realted decompensated cirrhosis.

To further determine the relationship between the plasma DAO level and the causes of readmission within 6 months, Cox regression analysis was performed for readmission of different causes. In HBV-related decompensated cirrhosis, plasma DAO $(\mathrm{HR}=1.184, P<0.05)$ was an independent risk factor for readmission due to HE within 6 months, as shown in Table 5. Plasma DAO level was associated with readmission due to ascites within 6 months, but was not an independent risk factor, as shown in Table 6. Plasma DAO level was not associated with readmission due to GI bleeding within 6 months, as shown in Table 7. Plasma DAO was associated with 6-month readmission due to SBP, but was not an independent risk factor, as shown in Table 8.

\section{The value of plasma DAO as a biomarker in the readmisson of HBV-related decompensated cirrhosis patients within 6-months}

The readmission rate of $\mathrm{HBV}$-related decompensated cirrhosis within 6 months was $26.7 \%$ (36/135). The mean readmission time of HBV-related decompensated cirrhosis at the end of 6-month was 2.924 (SE 0.255, 95\% CI: 2.425-3.424) months. The AUROC for DAO was 0.769 (SE 0.0457, 95\%CI: 0.689-0.837), which was significantly higher than HE [0.598 (SE 0.0403, 95\%CI: 0.511-0.682, $P<0.05$ ] and Child-Pugh score [0.652 (SE 0.0474, 95\%CI: $0.565-0.731, P<0.05]$, as shown in Fig. 3a. The plasma DAO level of $19.7 \mathrm{ng} / \mathrm{mL}$, with a sensitivity of $58.33 \%$ and specificity of $84.35 \%$, was selected as the cut-off value for readmission within 6 months in patients with HBV-related decompensated cirrhosis. Moreover, the readmission rate within 6 months of HBV-related decompensated cirrhosis patients with plasma DAO > $19.7 \mathrm{ng} / \mathrm{mL}$ group [58.3\% (21/36)] was higher than plasma $\quad \mathrm{DAO} \leq 19.7 \mathrm{ng} / \mathrm{mL}$ group $[15.2 \% \quad(15 / 99)]$. Futhermore, the readmission time with the level of plasma DAO $>19.7 \mathrm{ng} / \mathrm{mL} \quad[1.75$ months (SE 0.435, 95\%CI: 0.898-2.602)] was statistically different from patients with plasma DAO $\leq 19.7 \mathrm{ng} / \mathrm{mL}$ [3.65 months (SE 0.386, 95\%CI: 2.893-4.407); $P<0.05]$, as shown in Fig. 3b.

After 6-month follow-up, 6 of the 36 readmission HBV-related decompensated cirrhosis patients were readmitted due to HE. The DAO level of recurrent HE group was higher than non-recurrent HE group [29.7

Table 6 Uni- and multivariate Cox analysis of factors associated with readmission due to ascites in HBV-related decompensated cirrhosis patients

\begin{tabular}{|c|c|c|c|c|c|c|}
\hline \multirow[t]{2}{*}{ variable } & \multicolumn{3}{|c|}{ univariate } & \multicolumn{3}{|c|}{ mutlivariate } \\
\hline & $\overline{H R}$ & $95 \% \mathrm{Cl}$ & $P$ & $\overline{\mathrm{HR}}$ & $95 \% \mathrm{Cl}$ & $P$ \\
\hline Gender (male/female) * & 0.939 & $0.311-2.837$ & 0.911 & & & \\
\hline Age (year) & 1.053 & $0.979-1.132$ & 0.164 & & & \\
\hline $\operatorname{HBeAg}(+/-)^{*}$ & 1.351 & $0.450-4.057$ & 0.592 & & & \\
\hline $\mathrm{HBsAg}$ & 1.000 & $1.000-1.000$ & 0.565 & & & \\
\hline HBV-DNA $(+/-)^{*}$ & 1.318 & $0.404-4.302$ & 0.648 & & & \\
\hline ALT(IU/L) & 0.989 & $0.976-1.002$ & 0.088 & & & \\
\hline AST(IU/L) & 1.002 & $0.994-1.010$ & 0.595 & & & \\
\hline TBIL(umol/L) & 1.008 & $0.986-1.030$ & 0.467 & & & \\
\hline PTA & 0.995 & $0.962-1.028$ & 0.746 & & & \\
\hline $\operatorname{ALB}(\mathrm{g} / \mathrm{L})$ & 0.941 & $0.842-1.052$ & 0.284 & & & \\
\hline $\operatorname{WBC}\left(10^{9} / \mathrm{L}\right)$ & 1.071 & $0.944-1.215$ & 0.286 & & & \\
\hline $\mathrm{HGB}(\mathrm{g} / \mathrm{L})$ & 0.988 & $0.969-1.009$ & 0.256 & & & \\
\hline $\operatorname{PLT}\left(10^{9} / \mathrm{L}\right)$ & 0.997 & $0.986-1.008$ & 0.559 & & & \\
\hline $\mathrm{SBP}(+/-)^{*}$ & 3.400 & $1.109-10.419$ & 0.032 & 1.309 & $0.286-5.989$ & 0.729 \\
\hline $\operatorname{Ascites}(+/-)^{*}$ & 0.473 & $0.150-1.489$ & 0.201 & & & \\
\hline $\mathrm{HE}(+/-)^{*}$ & 2.102 & $0.606-7.290$ & 0.242 & & & \\
\hline Gl Bleeding $(+/-)^{*}$ & 4.126 & $1.442-11.810$ & 0.008 & 2.359 & $0.685-8.126$ & 0.174 \\
\hline Chilid-pugh score $(B / C) *$ & 2.929 & $1.066-8.044$ & 0.037 & 1.002 & $0.255-3.931$ & 0.998 \\
\hline $\mathrm{DAO}(\mathrm{ng} / \mathrm{mL})$ & 1.090 & $1.036-1.146$ & 0.001 & 1.065 & $0.987-1.150$ & 0.105 \\
\hline
\end{tabular}

HR Hazard ratio, $\mathrm{Cl}$ Confidence interval.

* Categorical variables 
Table 7 Uni- and multivariate Cox analysis of factors associated with readmission due to Gl Bleeding in HBV-related decompensated cirrhosis patients

\begin{tabular}{|c|c|c|c|c|c|c|}
\hline \multirow[t]{2}{*}{ variable } & \multicolumn{3}{|c|}{ univariate } & \multicolumn{3}{|c|}{ mutlivariate } \\
\hline & $\mathrm{HR}$ & $95 \% \mathrm{Cl}$ & $P$ & $\overline{\mathrm{HR}}$ & $95 \% \mathrm{Cl}$ & $P$ \\
\hline Gender (male/female) * & 0.532 & $0.143-1.982$ & 0.347 & & & \\
\hline Age (year) & 1.006 & $0.940-1.077$ & 0.863 & & & \\
\hline $\operatorname{HBeAg}(+/-)^{*}$ & 1.577 & $0.478-5.199$ & 0.454 & & & \\
\hline $\mathrm{HBsAg}$ & 1.000 & $1.000-1.000$ & 0.787 & & & \\
\hline $\mathrm{HBV}-\mathrm{DNA}(+/-)^{*}$ & 2.800 & $0.604-12.983$ & 0.188 & & & \\
\hline ALT(IU/L) & 0.998 & $0.989-1.008$ & 0.750 & & & \\
\hline AST(IU/L) & 0.999 & $0.990-1.008$ & 0.835 & & & \\
\hline TBIL(umol/L) & 0.995 & $0.971-1.020$ & 0.711 & & & \\
\hline PTA & 0.986 & $0.951-1.022$ & 0.434 & & & \\
\hline $\mathrm{ALB}(\mathrm{g} / \mathrm{L})$ & 0.983 & $0.875-1.104$ & 0.769 & & & \\
\hline $\mathrm{WBC}\left(10^{9} / \mathrm{L}\right)$ & 1.039 & $0.907-1.190$ & 0.584 & & & \\
\hline $\mathrm{HGB}(\mathrm{g} / \mathrm{L})$ & 0.972 & $0.951-0.993$ & 0.008 & 0.974 & $0.935-1.014$ & 0.200 \\
\hline $\operatorname{PLT}\left(10^{9} / \mathrm{L}\right)$ & 0.994 & $0.982-1.006$ & 0.334 & & & \\
\hline $\mathrm{SBP}(+/-)^{*}$ & 1.295 & $0.335-5.004$ & 0.708 & & & \\
\hline $\operatorname{Ascites}(+/-)^{*}$ & 0.875 & $0.228-3.357$ & 0.846 & & & \\
\hline $\mathrm{HE}(+/-)^{*}$ & 1.600 & $0.408-6.278$ & 0.500 & & & \\
\hline Gl Bleeding $(+/-)^{*}$ & 3.850 & $1.284-11.548$ & 0.016 & 1.122 & $0.131-9.578$ & 0.916 \\
\hline Chilid-pugh score $(B / C) *$ & 1.658 & $0.574-4.786$ & 0.350 & & & \\
\hline $\mathrm{DAO}(\mathrm{ng} / \mathrm{mL})$ & 1.032 & $0.980-1.086$ & 0.235 & & & \\
\hline
\end{tabular}

$H R$ Hazard ratio, $\mathrm{Cl}$ Confidence interval.

* Categorical variables

(24.5; 43.4) vs. $14.1(10.1 ; 19.0) \mathrm{ng} / \mathrm{mL}, P<0.001]$. The mean recurrent $\mathrm{HE}$ time was 2.442 (SE 0.589, 95\% CI: 1.084-3.801) months. The AUROC for DAO was 0.905 (SE 0.0452, 95\%CI: 0.842-0.949), which was significantly higher than Child-Pugh score [0.738 (SE 0.0763, 95\%CI: $0.655-0.810, P<0.05]$, as shown in Fig. 3c. The plasma DAO level of $21.04 \mathrm{ng} / \mathrm{mL}$, with a sensitivity of $88.9 \%$ and specificity of $82.5 \%$, was selected as the cut-off value for recurrent $\mathrm{HE}$ within 6 months in patients with HBVrelated decompensated cirrhosis. Moreover, the recurrent HE rate within 6 months with plasma DAO > 21.04 $\mathrm{ng} / \mathrm{mL}$ group $[23.3 \%(7 / 30)]$ was higher than plasma $\mathrm{DAO} \leq 21.04 \mathrm{ng} / \mathrm{mL}$ group $[1.9 \% \quad(2 / 105), \quad P<0.05]$. Futhermore, the readmission time with the level of plasma DAO > 21.04 ng/mL [2.176 months (SE 0.698, 95\%CI: 0.469-3.883)] was statistically different from patients with plasma DAO $\leq 21.04 \mathrm{ng} / \mathrm{mL}$ [3.375 months (SE 1.075, 95\%CI: 0.282-17.034); $P<0.05]$, as shown in Fig. 3d.

\section{Discussion}

HBV-related decompensated cirrhosis is often accompanied by gastrointestinal bleeding, hepatic encephalopathy, spontaneous peritonitis and other complications, resulting in repeated hospitalization [27]. Thus causes the serious economic burden to the society and the family. At present, many models and markers have been used for the prognosis of decompensated cirrhosis and the diagnosis of readmission [28]. In recent years, Many researchers have proved that gut flora disorder exists in liver cirrhosis patients [11]. In addition, intestinal microecology is related to the complications of liver cirrhosis, such as SBP, HE and prognosis of liver cirrhosis [29, 30]. Plasma DAO is the most sensitive indicator to predict intestinal barrier function [19]. Our previous study confirmed that plasma DAO could be used as a biological indicator to predict the 1-month mortality of acute-on-chronic hepatitis B liver failure. However, there were few studies on the diagnostic value of plasma DAO level in the readmission of patients with HBV-related decompensated cirrhosis within 6 months. This study found for the first time that the plasma DAO level in HBVrelated decompensated cirrhosis patients was significantly higher than that in compensated cirrhosis patients. After 6 months of follow-up, the plasma DAO level of the readmission patients was significantly higher than that of the non-readmission patients. We confirmed that plasma DAO level was an independent risk factor for 6-month readmission and predicted readmission for $\mathrm{HBV}$-related decompensated cirrhosis with 6 months. 
Table 8 Uni- and multivariate Cox analysis of factors associated with readmission due to SBP in HBV-related decompensated cirrhosis patients

\begin{tabular}{|c|c|c|c|c|c|c|}
\hline \multirow[t]{2}{*}{ variable } & \multicolumn{3}{|c|}{ univariate } & \multicolumn{3}{|c|}{ mutlivariate } \\
\hline & $\mathrm{HR}$ & $95 \% \mathrm{Cl}$ & P & $\mathrm{HR}$ & $95 \% \mathrm{Cl}$ & $P$ \\
\hline Gender (male/female) * & 2.676 & $0.729-9.827$ & 0.138 & & & \\
\hline Age (year) & 1.104 & $0.993-1.28$ & 0.068 & & & \\
\hline $\operatorname{HBeAg}(+/-)^{*}$ & 0.732 & $0.196-2.738$ & 0.643 & & & \\
\hline $\mathrm{HBsAg}$ & 1.000 & $1.000-1.000$ & 0.676 & & & \\
\hline $\mathrm{HBV}-\mathrm{DNA}(+/-)^{*}$ & 0.837 & $0.204-3.427$ & 0.805 & & & \\
\hline ALT(IU/L) & 0.958 & $0.928-0.990$ & 0.070 & & & \\
\hline AST(IU/L) & 0.998 & $0.987-1.010$ & 0.777 & & & \\
\hline TBIL(umol/L) & 0.999 & $0.970-1.029$ & 0.933 & & & \\
\hline PTA & 1.007 & $0.966-1.049$ & 0.755 & & & \\
\hline $\mathrm{ALB}(\mathrm{g} / \mathrm{L})$ & 0.926 & $0.802-1.069$ & 0.294 & & & \\
\hline WBC(109/L) & 1.030 & $0.870-1.218$ & 0.735 & & & \\
\hline $\mathrm{HGB}(\mathrm{g} / \mathrm{L})$ & 0.987 & $0.962-1.013$ & 0.326 & & & \\
\hline $\operatorname{PLT}\left(10^{9} / \mathrm{L}\right)$ & 1.002 & $0.989-1.016$ & 0.748 & & & \\
\hline $\operatorname{SBP}(+/-)^{*}$ & 1.395 & $0.275-7.080$ & 0.688 & & & \\
\hline $\operatorname{Ascites}(+/-)^{*}$ & 5.944 & $1.562-22.620$ & 0.009 & 5.200 & $0.730-37.047$ & 0.100 \\
\hline $\mathrm{HE}(+/-)^{*}$ & 5.286 & $1.327-21.050$ & 0.018 & 3.529 & $0.616-20.224$ & 0.157 \\
\hline Gl Bleeding $(+/-)^{*}$ & 4.682 & $1.248-17.566$ & 0.022 & 1.704 & $0.239-12.169$ & 0.595 \\
\hline Chilid-pugh score $(B / C) *$ & 3.308 & $0.883-12.389$ & 0.076 & & & \\
\hline $\mathrm{DAO}(\mathrm{ng} / \mathrm{mL})$ & 1.064 & $1.004-1.127$ & 0.037 & 1.072 & $0.990-1.160$ & 0.085 \\
\hline
\end{tabular}

HR Hazard ratio, $\mathrm{Cl}$ Confidence interval

* Categorical variables

Imbalance of intestinal flora is involved in the occurrence and development of a variety of diseases [31]. The liver and intestinal have a close anatomical and functional relationship. Intestinal microbiota play an important role in the development of liver cirrhosis through the gut-liver axis and microbiota-liver axis [32, 33]. In patients with HBV-related cirrhosis, there are changes both in intestinal flora outcome and function [34]. Portal hypertension and intestinal congestion can lead to increased permeability of the intestinal wall [35]. When intestinal wall permeability increases, intestinal bacteria and their metabolites are more likely to enter extraintestinal organs, thus inducing complications such as $\mathrm{HE}$ and SBP [36]. Overgrowth of intestinal flora, bacteria translocation and increased permeability of intestinal wall promote each other, thus forming a vicious cycle [37]. Therefore, changes in intestinal wall permeability play an important role in HBV-related liver cirrhosis [15]. At present, the detection of intestinal wall permeability mostly used the indirect method. Plasma DAO was the most sensitive indicator to predict intestinal barrier function.

Our study found that plasma DAO levels were significantly elevated in patients with SBP, GI bleeding, and
HE. Therefore, in patients with decompensated cirrhosis, plasma DAO levels reflect the severity of cirrhosis in patients. TLRs (Toll-like receptors) are natural immune receptors in the liver, mainly expressed in Kupffer cells, endothelial cells, dendritic cells, bile duct epithelial cells, hepatic stellate cells and hepatocytes [38]. There are many pathogen-associated molecular patterns (PAMPs) in the gut, and these PAMPs cannot reach the systemic circulation due to the presence of intestinal barrier function. Lipopolysaccharide (LPS) is a component of the cell wall of Gram-negative bacteria and is currently the most studied PAMPs. Studies have shown that when the intestinal barrier function is impaired, LPS enters the liver through the portal system, inducing activation of liver macrophage Kupffer cells. Kupffer cells trigger the release of factors such as TNF- $\alpha$ through NF-kB-mediated mechanisms which activates specific intracellular pathways through cascades, induce apoptosis, cause liver damage, and aggravate cirrhosis [39]. On the other hand, LPS, as a hepatic toxin, causes an acute inflammatory reaction in the liver, which is characterized by polymorphonuclear cell aggregation, neutrophils releasing reactive oxygen metabolites, proteases, etc., causing liver damage to be aggravated [40]. 


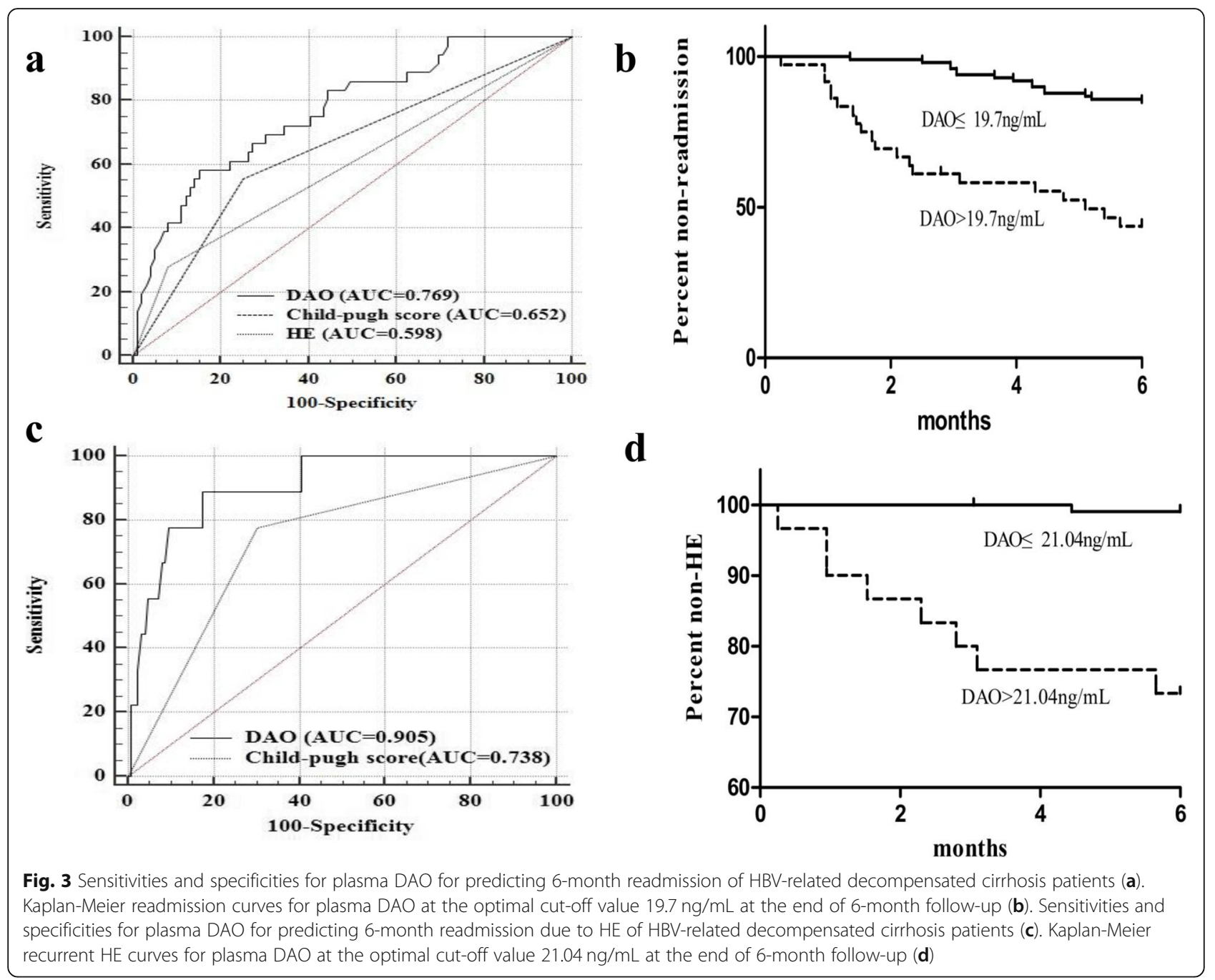

Our study found that in patients with HBV-related decompensated cirrhosis, plasma DAO levels were significantly higher in patients who were readmitted after 6 months of follow-up than those who did not. We used the Cox proportional hazards regression model to find that plasma DAO levels and HE were independent risk factors for readmission of patients with HBV-related decompensated cirrhosis within 6 months. Considering Child-pugh scores commonly used for liver function grading in patients with cirrhosis, we used K-M survival analysis to analyze the diagnostic value of plasma DAO levels, HE, and Child-pugh scores for readmission in patients with decompensated cirrhosis. We found that the AUROC of DAO was significantly higher than the HE and Child-Pugh scores. The reasons for readmission of patients who were readmitted to liver-related diseases within 6 months of follow-up were mainly HE, SBP, GI bleeding, and massive ascites. Analysis of the reasons, mainly have the following points: Liver cirrhosis and portal hypertension affect intestinal dysfunction, abnormal secretion of bile salts, leading to excessive growth of intestinal bacteria [33]; Intestinal flora structure of patients with cirrhosis and functional changes, such as the increase in the number of pathogenic Enterobacteriaceae and Streptococcus [9-11]; Increased intestinal permeability, leading to intestinal flora translocation [41]. Ammonia has long been regarded as a core factor in the pathogenesis of HE in patients with cirrhosis. The ammonia in the blood circulation is mainly derived from the decomposition of amino acids in the intestinal bacteria and the intestinal circulation of urea [42]. When the permeability of the intestinal wall increases, the amount of ammonia in the intestine increases, which increases the risk of HE. SBP is a dangerous complication of decompensated patients with cirrhosis [43]. Gram-negative bacteria are the most common pathogenic bacteria of SBP, accounting for about 80\%, especially Escherichia coli [44], so it is believed that the infection of spontaneous bacterial peritonitis is mainly intestinal infection [45]. The translocation of bacteria to the mesenteric lymph nodes is an important starting point 
for SBP [13]. SBP is associated with impaired intestinal motility, intestinal bacterial overgrowth and intestinal barrier dysfunction. Intestinal barrier dysfunction is the most critical link. When intestinal barrier function is impaired, intestinal bacteria are increased. The possibility of translocation to the mesenteric lymph nodes, which has been confirmed in the rat liver cirrhosis model. In the mesenteric lymph nodes of a mouse model of cirrhosis, the researchers found bacteria homologous to spontaneous peritonitis [46].

To further validate the diagnostic value of plasma DAO for patients readmitted with HBV-related decompensated cirrhosis within 6 months, we took plasma DAO level of $19.7 \mathrm{ng} / \mathrm{mL}$, sensitivity of $58.33 \%$, specificity of $84.35 \%$, as the cut-off value of patients with HBV-related decompensated cirrhosis within 6 months. We found that the readmission rate of DAO $>19.7 \mathrm{ng} /$ $\mathrm{mL}$ patients was significantly higher than that of DAO $\leq$ $19.7 \mathrm{ng} / \mathrm{mL}$ group, and the cumulative readmission time of the two groups was statistically different. In summary, plasma DAO can predict readmission of patients with HBV-realted decompensated cirrhosis within 6 months.

However, our study had some limitations. The first and foremost, we did single-center research, not multicenter research. Second, this study without cohort validation. Third, the exact mechanism of DAO involvement in the process of liver cirrhosis was still unclear, and we will continue to conduct further research on this issue.

\section{Conclusions}

In summary, we first demonstrated that the plasma DAO might be predict the readmission with 6 months of HBV-related decompengsated cirrhosis. Plasma DAO level $>19.7 \mathrm{ng} / \mathrm{mL}$ predicts high rate of 6 -month readmission in patients with HBV-related decompensated cirrhosis.

\section{Abbreviations \\ ACHBLF: Acute-on-chronic hepatitis B liver failure; AFP: Alpha fetal protein; ALB: Albumin; ALT: Alanine aminotransferase; AST: Aspartate aminotransferase; $A \cup C$ : The area under the receiver operating characteristic curve; CHB: Chronic hepatitis B; CPT: Child-Pugh-Turcotte; Cr: Creatinine; DAO: Diamine oxidase; ELISA: Enzyme-linked immunosorbent assay; Gl bleeding: Gastrointestinal bleeding; HBeAg: Hepatitis B e antigen; HbsAg: Hepatitis B surface antigen; HBV: Hepatitis B virus; HC: Healthy control; HE: Hepatic encephalopathy; HGB: Haemoglobin; INR: International normalized ratio; MELD: Model for end-stage liver disease; PLT: Platelet; PTA: Prothrombin activity; ROC: Receiver operating characteristic curve; SBP: Spontaneous bacterial peritonitis; TBIL: Total bilirubin; WBC: White blood cell}

\section{Acknowledgements}

We would like to acknowledge all patients who have participated in this study.

\section{Authors' contributions}

KW and FCL designed the study. FCL, YCF and YKL performed the experiment and data analysis. FCL wrote the manuscript, YCF and KW revised the manuscript. All authors read and approved the final manuscript.

\section{Funding}

The study was supported by grants from the Key Project of Chinese Ministry of Science and Technology (2017ZX10202202 and 2018ZX10302206), the National Natural Science Foundation of China(81970522) and the Key Research and Development Project of Shanodng Province(2019GSF108023)

\section{Availability of data and materials}

All relevant information is provided in this current manuscript.

\section{Ethics approval and consent to participate}

According to the guidelines of the Helsinki declaration, all participants were approved in writing by the local research and ethics committee of Qilu hospital of Shandong University.

\section{Consent for publication}

Not applicable.

\section{Competing interests}

The authors declare that they have no competing interest.

\section{Author details}

${ }^{1}$ Department of Hepatology, Qilu Hospital of Shandong University, Wenhuaxi Road 107\#, Jinan 250012, China. ${ }^{2}$ Institute of Hepatology, Shandong University, Wenhuaxi Road 107\#, Jinan 250012, China. ${ }^{3}$ Department of Nuclear Medicine, Qilu Hospital of Shandong University, Wenhuaxi Road 107\#, Jinan 250012, China.

Received: 22 June 2019 Accepted: 5 September 2019

Published online: 18 September 2019

\section{References}

1. Collaborators GBDRF, Forouzanfar MH, Alexander $\mathrm{L}$, Anderson HR, Bachman VF, Biryukov S, et al. Global, regional, and national comparative risk assessment of 79 behavioural, environmental and occupational, and metabolic risks or clusters of risks in 188 countries, 1990-2013: a systematic analysis for the global burden of disease study 2013. Lancet. 2015; 386(10010):2287-323.

2. Wang SB, Wang JH, Chen J, Giri RK, Chen MH. Natural history of liver cirrhosis in South China based on a large cohort study in one center: a follow-up study for up to 5 years in 920 patients. Chin Med J. 2012; 125(12):2157-62.

3. Fattovich G, Bortolotti F, Donato F. Natural history of chronic hepatitis B: special emphasis on disease progression and prognostic factors. J Hepatol. 2008;48(2):335-52.

4. Fontana RJ. Management of patients with decompensated HBV cirrhosis. Semin Liver Dis. 2003;23(1):89-100.

5. Kanwal F, Gralnek IM, Hays RD, Zeringue A, Durazo F, Han SB, et al. Healthrelated quality of life predicts mortality in patients with advanced chronic liver disease. Clin Gastroenterol Hepatol. 2009;7(7):793-9.

6. Pugh RN, Murray-Lyon IM, Dawson JL, Pietroni MC, Williams R. Transection of the oesophagus for bleeding oesophageal varices. $\mathrm{Br} J$ Surg. 1973;60(8):646-9.

7. Gosalbes MJ, Durban A, Pignatelli M, Abellan JJ, Jimenez-Hernandez N, Perez-Cobas AE, et al. Metatranscriptomic approach to analyze the functional human gut microbiota. PLoS One. 2011;6(3):e17447.

8. He Z, Deng Y, Zhou J. Development of functional gene microarrays for microbial community analysis. Curr Opin Biotechnol. 2012;23(1):49-55.

9. Xu M, Wang B, Fu Y, Chen Y, Yang F, Lu H, et al. Changes of fecal Bifidobacterium species in adult patients with hepatitis B virus-induced chronic liver disease. Microb Ecol. 2012;63(2):304-13.

10. Chen Y, Yang F, Lu H, Wang B, Chen Y, Lei D, et al. Characterization of fecal microbial communities in patients with liver cirrhosis. Hepatology. 2011; 54(2):562-72.

11. Qin N, Yang F, Li A, Prifti E, Chen Y, Shao L, et al. Alterations of the human gut microbiome in liver cirrhosis. Nature. 2014;513(7516):59-64.

12. Backhed F, Ley RE, Sonnenburg JL, Peterson DA, Gordon Jl. Host-bacterial mutualism in the human intestine. Science. 2005;307(5717):1915-20.

13. Berg RD, Garlington AW. Translocation of certain indigenous bacteria from the gastrointestinal tract to the mesenteric lymph nodes and other organs in a gnotobiotic mouse model. Infect Immun. 1979;23(2):403-11. 
14. Bourlioux P, Koletzko B, Guarner F, Braesco V. The intestine and its microflora are partners for the protection of the host: report on the Danone symposium "the intelligent intestine," held in Paris, June 14, 2002. Am J Clin Nutr. 2003;78(4):675-83.

15. Wiest R, Garcia-Tsao G. Bacterial translocation (BT) in cirrhosis. Hepatology. 2005;41(3):422-33.

16. McGrath AP, Caradoc-Davies T, Collyer CA, Guss JM. Correlation of active site metal content in human diamine oxidase with trihydroxyphenylalanine quinone cofactor biogenesis. Biochemistry. 2010;49(38):8316-24.

17. Luk GD, Bayless TM, Baylin SB. Diamine oxidase (histaminase). A circulating marker for rat intestinal mucosal maturation and integrity. J Clin Invest. 1980;66(1):66-70.

18. Zhou S, Xu CD, Chen SN, Liu W. Correlation of intestinal mucosal injury with serum diamine oxidase. Zhonghua Er Ke Za Zhi. 2006;44(2):93-5.

19. Fukudome I, Kobayashi M, Dabanaka K, Maeda H, Okamoto K, Okabayashi T, et al. Diamine oxidase as a marker of intestinal mucosal injury and the effect of soluble dietary fiber on gastrointestinal tract toxicity after intravenous 5fluorouracil treatment in rats. Med Mol Morphol. 2014:47(2):100-7.

20. Petersen J, Raithel M, Schwelberger HG. Analysis of diamine oxidase gene polymorphisms in patients with inflammatory bowel disease. Inflamm Res. 2001;50(Suppl 2):S68-9.

21. Baylin SB, Abeloff MD, Wieman KC, Tomford JW, Ettinger DS. Elevated histaminase (diamine oxidase) activity in small-cell carcinoma of the lung. $N$ Engl J Med. 1975;293(25):1286-90.

22. Li FC, Li YK, Fan YC, Wang K. Plasma concentration of diamine oxidase (DAO) predicts 1-month mortality of acute-on-chronic hepatitis B liver failure. Clin Chim Acta. 2018;484:164-70.

23. Ruan P, Gong ZJ, Zhang QR. Changes of plasma D(-)-lactate, diamine oxidase and endotoxin in patients with liver cirrhosis. Hepatobiliary Pancreat Dis Int. 2004;3(1):58-61.

24. Tian $\mathrm{H}$, Wang KF, Wu TJ. Effect of total parenteral nutrition with supplementation of glutamine on the plasma diamine oxidase activity and D-lactate content in patients with multiple organ dysfunction syndrome. Zhongguo Wei Zhong Bing Ji Jiu Yi Xue. 2006;18(10):616-8.

25. Hellmann F, Verdi M, Schlemper BR Jr, Caponi S. 50th anniversary of the declaration of Helsinki: the double standard was introduced. Arch Med Res. 2014;45(7):600-1.

26. Fukui $H$, Saito H, Ueno Y, Uto H, Obara K, Sakaida I, et al. Evidence-based clinical practice guidelines for liver cirrhosis 2015. J Gastroenterol. 2016;51(7):629-50.

27. Lim YL, Choi E, Jang YO, Cho YZ, Kang YS, Baik SK, et al. Clinical implications of the serum Apelin level on portal hypertension and prognosis of liver cirrhosis. Gut Liver. 2016;10(1):109-16.

28. Singal AG, Rahimi RS, Clark C, Ma Y, Cuthbert JA, Rockey DC, et al. An automated model using electronic medical record data identifies patients with cirrhosis at high risk for readmission. Clin Gastroenterol Hepatol. 2013;11(10):1335-41 e1.

29. Chen Y, Guo J, Shi D, Fang D, Chen C, Li L. Ascitic bacterial composition is associated with clinical outcomes in cirrhotic patients with culture-negative and non-neutrocytic ascites. Front Cell Infect Microbiol. 2018;8:420.

30. Shao L, Ling Z, Chen D, Liu Y, Yang F, Li L. Disorganized gut microbiome contributed to liver cirrhosis progression: a meta-omics-based study. Front Microbiol. 2018;9:3166.

31. Othman M, Aguero R, Lin HC. Alterations in intestinal microbial flora and human disease. Curr Opin Gastroenterol. 2008;24(1):11-6.

32. Dapito DH, Mencin A, Gwak GY, Pradere JP, Jang MK, Mederacke I, et al. Promotion of hepatocellular carcinoma by the intestinal microbiota and TLR4. Cancer Cell. 2012;21(4):504-16.

33. Chassaing B, Etienne-Mesmin L, Gewirtz AT. Microbiota-liver axis in hepatic disease. Hepatology. 2014;59(1):328-39.

34. Pardo A, Bartoli R, Lorenzo-Zuniga V, Planas R, Vinado B, Riba J, et al. Effect of cisapride on intestinal bacterial overgrowth and bacterial translocation in cirrhosis. Hepatology. 2000;31(4):858-63.

35. Bhonchal S, Nain CK, Prasad KK, Nada R, Sharma AK, Sinha SK, et al. Functional and morphological alterations in small intestine mucosa of chronic alcoholics. J Gastroenterol Hepatol. 2008;23(7 Pt 2):e43-8.

36. Riordan SM, Duncombe VM, Thomas MC, Nagree A, Bolin TD, Mclver CJ, et al. Small intestinal bacterial overgrowth, intestinal permeability, and nonalcoholic steatohepatitis. Gut. 2002;50(1):136-8.

37. Husebye E, Hellstrom PM, Sundler F, Chen J, Midtvedt T. Influence of microbial species on small intestinal myoelectric activity and transit in germ-free rats. Am J Physiol Gastrointest Liver Physiol. 2001;280(3):G368-80.

38. Seki E, Schnabl B. Role of innate immunity and the microbiota in liver fibrosis: crosstalk between the liver and gut. J Physiol. 2012;590(3):447-58.
39. Bilzer M, Roggel F, Gerbes AL. Role of Kupffer cells in host defense and liver disease. Liver Int. 2006;26(10):1175-86.

40. Compare D, Coccoli P, Rocco A, Nardone OM, De Maria S, Carteni M, et al. Gut--liver axis: the impact of gut microbiota on non alcoholic fatty liver disease. Nutr Metab Cardiovasc Dis. 2012;22(6):471-6.

41. Tripathi A, Debelius J, Brenner DA, Karin M, Loomba R, Schnabl B, et al. The gut-liver axis and the intersection with the microbiome. Nat Rev Gastroenterol Hepatol. 2018;15(7):397-411.

42. Woodhouse CA, Patel VC, Singanayagam A, Shawcross DL. Review article: the gut microbiome as a therapeutic target in the pathogenesis and treatment of chronic liver disease. Aliment Pharmacol Ther. 2018:47(2):192-202.

43. Novella M, Sola R, Soriano G, Andreu M, Gana J, Ortiz J, et al. Continuous versus inpatient prophylaxis of the first episode of spontaneous bacterial peritonitis with norfloxacin. Hepatology. 1997;25(3):532-6.

44. Wiest $\mathrm{R}$, Lawson M, Geuking M. Pathological bacterial translocation in liver cirrhosis. J Hepatol. 2014;60(1):197-209.

45. Bellot P, Frances $R$, Such J. Pathological bacterial translocation in cirrhosis: pathophysiology, diagnosis and clinical implications. Liver Int. 2013:33(1):31-9.

46. Yan AW, Fouts DE, Brandl J, Starkel P, Torralba M, Schott E, et al. Enteric dysbiosis associated with a mouse model of alcoholic liver disease. Hepatology. 2011;53(1):96-105.

\section{Publisher's Note}

Springer Nature remains neutral with regard to jurisdictional claims in published maps and institutional affiliations.
Ready to submit your research? Choose BMC and benefit from:

- fast, convenient online submission

- thorough peer review by experienced researchers in your field

- rapid publication on acceptance

- support for research data, including large and complex data types

- gold Open Access which fosters wider collaboration and increased citations

- maximum visibility for your research: over $100 \mathrm{M}$ website views per year

At $\mathrm{BMC}$, research is always in progress.

Learn more biomedcentral.com/submissions 